\title{
THE GREEN INFRASTRUCTURE OF A HIGHLY-URBANIZED NEOTROPICAL CITY: THE ROLE OF THE URBAN VEGETATION IN PRESERVING NATIVE BIODIVERSITY
}

\author{
A INFRAESTRUTURA VERDE DE UMA METRÓPOLE NEOTROPICAL: O PAPEL DA \\ VEGETAÇÃO URBANA PARA A PRESERVAÇÃO DA BIODIVERSIDADE
}

\author{
João Carlos de Castro Pena ${ }^{1}$, Danilo Marques de Magalhães², Ana Clara Mourão Moura ${ }^{3}$, \\ Robert J. Young ${ }^{4}$, Marcos Rodrigues ${ }^{5}$
}

\begin{abstract}
The composition of the urban vegetation that comprises the green infrastructure of a highly urbanized Neotropical city was mapped and described in order to assess how it can be used to preserve and maintain urban biodiversity. Supervised classification was used, followed by Map Algebra methodology, to identify the elements that comprise the green infrastructure of the southern region of Belo Horizonte (Minas Gerais, Brazil). Species composition of the street trees community was also assessed. Almost half of the study area is occupied by 12 types of woody and herbaceous vegetation, composed mostly by urban parks and gardens. Forty-one percent of the almost 90,000 street trees is composed by 10 species from which only four are native. These results show that the green infrastructure of this urban landscape is comprised by a large amount of different types of green elements, and has a great potential for biodiversity conservation. However, management strategies are needed such as better planning of the urban afforestation process, increasing street tree species richness. This study is the first step towards a better understanding of how such urban landscape influences local biodiversity.
\end{abstract}

Keywords: Belo Horizonte; Biodiversity conservation; Map algebra; Rapid eye image; Urban landscape.

\section{RESUMO}

A vegetação urbana que compõe a infraestrutura verde de uma metrópole Neotropical foi mapeada e descrita, e avaliou-se como ela pode ser utilizada para a preservação da biodiversidade urbana. Foi utilizada classificação supervisionada, seguida de Álgebra de Mapas para identificação dos elementos que compõem a infraestrutura verde da regional centro-sul de Belo Horizonte (Minas Gerais, Brasil). Também foi avaliada a composição de espécies da arborização viária da área de estudo. Quase metade da regional centro-sul de Belo Horizonte é ocupada por 12 tipos de vegetação arbórea e herbácea, compostos principalmente por parques e jardins. Das aproximadamente 90 mil árvores que compõem a arborização viária, $41 \%$ é composto por 10 espécies; destas, somente quatro são nativas. Estes resultados mostram que a infraestrutura verde desta paisagem urbana possui alta riqueza e quantidade de elementos, apresentando um grande potencial para a preservação da biodiversidade urbana. Entretanto, estratégias de manejo adequadas, como melhor planejamento do processo de florestamento urbano precisam ser adotadas, com plantio de maior quantidade de espécies de árvores. Este estudo é o primeiro passo para uma melhor compreensão de como esta paisagem urbana influencia a biodiversidade local.

Palavras-chave: Belo Horizonte; Conservação da biodiversidade; Álgebra de mapas; Imagem rapid eye; Paisagem urbana.

Recebido em 30.09.2016 e aceito em 20.12.2016

1 Biólogo, MSc., Doutorando no Programa de Pós-Graduação em Ecologia Conservação e Manejo de Vida Silvestre da Universidade Federal de Minas Gerais. Belo Horizonte, Minas Gerais, Brasil E-mail: joaocpena@gmail.com

2 Geógrafo, MSc., Professor no Centro Universitário de Belo Horizonte. Belo Horizonte, Minas Gerais, Brasil E-mail: danilommagalhaes@gmail.com

3 Arquiteta, Dra., Professora na Escola de Arquitetura da Universidade Federal de Minas Gerais. Belo Horizonte, Minas Gerais, Brasil E-mail: anaclaramoura@yahoo.com

4 Biólogo, Dr., Professor na School of Environmental and Life Sciences da University of Salford Manchester. Salford, Reino Unido E-mail: r.j.young@salford.ac.uk

5 Biólogo, Dr., Professor no Departamento de Zoologia da Universidade Federal de Minas Gerais. Belo Horizonte, Minas Gerais, Brasil E-mail: ornito@icb.ufmg.br 


\section{INTRODUCTION}

Urban green infrastructure is an ecological network which restructures the urban landscape, mimicking natural processes to maintain the functionality of the urban ecosystem (HERZOG, 2013). It also provides the ecosystem services that are equally necessary for human well-being and biodiversity conservation. Within cities the green infrastructure is comprised by different areas and pervious surfaces, partially or completely dominated by different vegetation types. They include forest patches, green roofs, gardens, grasslands, green walls, street trees, parks and squares with different management types and history of human influences.

Investments on green infrastructure result in positive outcomes for the urban population. Such benefits surpass the relatively low initial income necessary for improvements on vegetation (SOARES et al., 2011). Urban trees can reduce energy consumption, storm water runoff and pollutants exposure, as well as increase real estate values (SOARES et al., 2011). The green infrastructure is also directly important to maintain and preserve biodiversity inside cities. Street trees' species composition influences bird feeding guilds that use street's vegetation (YOUNG; DANIELS; JOHNSTON, 2007) and the amount of native street tree species increases the amount of native bird species within urban parks (IKIN et al. 2013).

Neotropical cities are experiencing one of the most rapid and intense urbanization processes worldwide (UNITED NATIONS, 2014). However, little is known about how urban vegetation affects the urban biodiversity and human wellbeing (KENIGER et al., 2013). This is a worrisome fact, because Neotropical urban landscapes are often located within and nearby highly biologically productive areas, such as coastal zones and major riverine systems (MCDONALD; MARCOTULLIO; GÜNERALP, 2013). Although highly urbanized, Neotropical cities have some of the world's largest social and economic inequities, which can threaten biodiversity hotspots (PAUCHARD; BARBOSA, 2013). The attempts to solve the serious social and infrastructural problems within these cities are often held disregarding environmental issues; therefore it is necessary to change the perception that separates the ecological factors from other urban problems (poverty, housing, food and unemployment) once these issues interact, and ecological solutions often exist and are viable (HERZOG, 2013).

This study aimed to: (1) map and describe the urban vegetation elements that compose the green infrastructure in Belo Horizonte, a Neotropical urban centre; and (2) investigate how they can be used to preserve native biodiversity within the urban landscape. The knowledge concerning the structure of an urban landscape is the first step to understand how it influences the organisms capable of living and persisting within cities (both human and non-human organisms) and for the appliance of adequate management. 


\section{MATERIAL AND METHODS}

\section{Study area}

Our study area is the southern region of Belo Horizonte city (19W 55' 37", 43S 56' 34") one of the first planned cities in Brazil and Minas Gerais state capital (Figure 1). The southern region of Belo Horizonte has $31.7 \mathrm{~km}^{2}$, which comprises the oldest part of the city, an area of approximately $9 \mathrm{~km}^{2}$, established in 1897 and designed for 200,000 inhabitants. It was conceived under the "garden city" concept, being famous during the first decades after its foundation for the high density of gardens, public squares and leafy streets. In the 1960s, after facing an explosive growth of its population (800,000 inhabitants in 1962), the city suffered intense landscape changes: reducing the quantity and diversity of street trees and gardens for the expansion of the urban infrastructure.

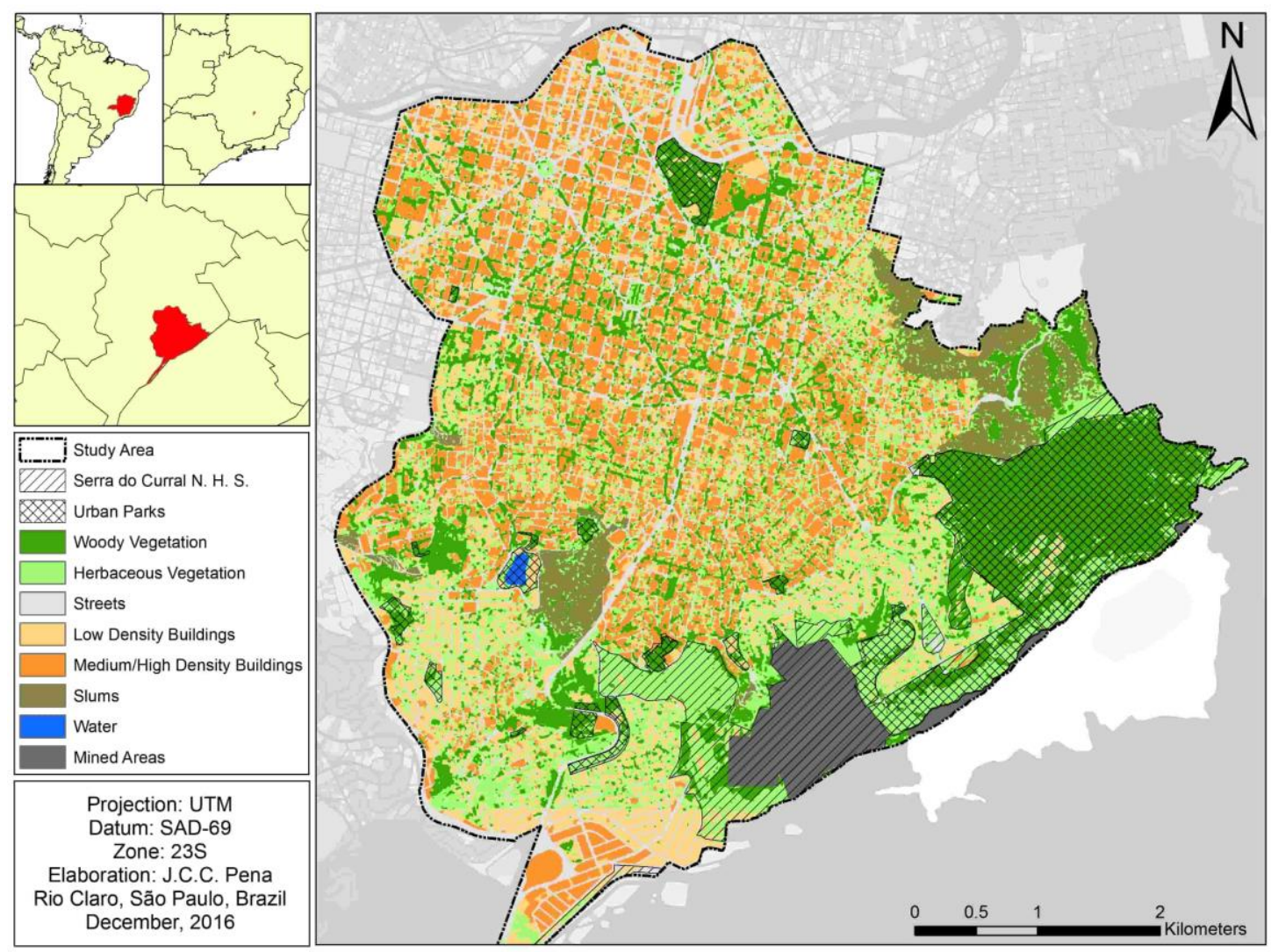

Figura 1. Mapa de uso do solo da regional centro-sul do município de Belo Horizonte (Minas Gerais, Brasil), com destaque para os parques municipais e a porção da Serra do Curral considerada patrimônio nacional (Serra do Curral N.H.S.)

Figure 1. Land use type of the southern region of Belo Horizonte (Minas Gerais, Brazil), highlighting the municipal parks and the Serra do Cipó National Heritage Site (N.H.S.) 
The most infamous event was the cutting of hundreds of Ficus benjamina L. (Weeping figs) located in one of the main avenues of Belo Horizonte in 1963 (DUARTE, 2007). Today, Belo Horizonte's landscape comprises an area of approximately $331 \mathrm{~km}^{2}$ and its public green infrastructure is composed of scattered green areas, public squares and parks, and street trees composed mainly of exotic species embedded in an urban matrix. This historical background of landscape changes makes this city an interesting model to evaluate the composition of the urban vegetation and how it can be used for biodiversity conservation in the Neotropical region.

\section{Mapping urban and vegetation features}

The identification of the urban and vegetation features of Belo Horizonte's landscape was made by supervised classification of RapidEye's satellite images from the year 2010. This satellite is equipped with REIS (RapidEye Earth Imaging System) sensors, operating in five frequency bands, three in the electromagnetic spectrum of the region known as "visible" (bands 1, 2 and 3); the other frequency bands - Red-Edge (Band 4: 690-730mm) and near infrared (Band 5: 760-850mm) - are used for vegetation monitoring, as they are able to identify changes in chlorophyll content and in plant cell structure, respectively. We used two $25 \times 25 \mathrm{~km}$ images, with $5 \mathrm{~m}$ spatial resolution and 12 bits (4096 shades of grey). The method adopted was segmentation followed by definition of classification keys (composed by water, dense vegetation, medium vegetation, herbaceous vegetation and urban components), and the application of MaxVer algorithm (Maximum Likelihood Classification) with accuracy of $85 \%$.

Due to the images' characteristics (spatial and spectral resolution) it was possible to clearly identify the volumetric conditions of the vegetation (dense, medium or herbaceous vegetation) and to separate them from anthropic elements (buildings and roads). Nonetheless, it was not possible to differentiate the urban elements (such as houses, buildings and roads) as well as the different types or uses in green elements that compose the green infrastructure (such as gardens, parks, street trees and squares). To allow this differentiation we adopted the Map Algebra methodology (MCHARG, 1969), with the aim of crossing distinct data types and get accurate information on vegetation and urban elements, which is described below.

A land use cover map in vector format of Belo Horizonte from the year 2012 was obtained (BELO HORIZONTE, 1996). This map allows the identification of each land use type of each lot inside of the city blocks located in the study area (Appendix A). It is worth mentioning that this file only has the information within city blocks; that is, in roads, public squares and roundabouts there are no assigned information.

The vector data were converted to raster format to allow greater flexibility in data processing and maintaining a common scale for analysis. In a raster image, each pixel records 
the description of the elements that compose it (e.g. vegetation type) in the form of a digital numerical value. Thus, during the conversion process a value was assigned to each of the land use types in order to identify them in the Map Algebra process. These values were chosen in a qualitative way; that is, they do not represent any hierarchy of information, only a distinction of classes (Appendix A). Some land use types, considered to fall within our interests were grouped into numerical classes (Appendix A). Both images were reclassified using the Reclassify tool from ArcGIS 10.2 software. The three categories of the supervised classification map were reclassified to values in the range of 1-10 [one for woody vegetation (dense + medium vegetation), two for herbaceous vegetation and 10 for urban elements]. The land use map categories were reclassified to values in the range of 100-1000 (Appendix A). Both reclassified maps were then, overlapped. Using the final pixel values, it is possible to know which categories of both maps were overlapped (Appendix B). Each numerical final value was replaced by a new land use type name in the final map (Figure 1).

As roads, public squares and roundabouts have no assigned information in the land use map, all pixels with values equal to one, two and 10 (values attributed to the supervised classification map) are related to those elements in the final map. Thus, pixels with value equal to one are composed by, for example, street trees and woody vegetation in squares; pixels with value equal to two are composed by, for example, roadside grass, public gardens and squares; pixels with value equal to 10 are composed by streets, avenues and roads.

To assess the contribution of each land use type to the urban landscape, the total number of pixels of each class was multiplied by $25 \mathrm{~m}^{2}$ (pixel resolution). In this way was possible to know the quantity of herbaceous and woody vegetation composed by parks, street trees, public squares and gardens throughout the landscape.

\section{Composition of street trees' community}

Currently, the afforestation process in most Neotropical cities located in countries like Brazil is usually based on a relatively small pool of commonly planted, often exotic tree species (MORO; CASTRO, 2015; PAUCHARD; BARBOSA, 2013). Furthermore, street tree species composition influences urban biodiversity (IKIN et al., 2013; YOUNG et al., 2007). Therefore, besides assessing the composition and amount of different land use types attributed to the urban vegetation, we also assessed the street tree species community composition.

Information about species and geographic location of all individual street trees in the study area was obtained from Belo Horizonte's Tree Information System (SIIA-BH), which was designed to register information on trees located in public places (BELO HORIZONTE, 2016). Approximately 90,000 trees were inventoried through the southern region of Belo Horizonte, 
totalling 475 species. From this database, we evaluated the frequency of the abundances of the street tree species. Among the ten dominant tree species, we identified exotic and native tree species and their relative proportions in relation to the street trees' community.

\section{RESULTS AND DISCUSSION}

Within the study region, were found 6 different types of herbaceous and 6 different types of woody vegetation distributed in parks, streets and squares, gardens, wastelands, slums and mined areas (Figure 1, Table 1). The proportion of build-up area is $54.46 \%$ of the territory $\left(17.26 \mathrm{~km}^{2}\right)$, which means that almost half of this urban landscape $\left(14.44 \mathrm{~km}^{2}\right)$ is occupied by woody $\left(22.56 \%-7,15 \mathrm{~km}^{2}\right)$ and herbaceous vegetation $\left(22.98 \%-7.29 \mathrm{~km}^{2}\right)$ (Table 1). Parks contained the largest proportion of woody vegetation $\left(38.51 \%-2.75 \mathrm{~km}^{2}\right)$, followed by street trees and public squares $\left(24.63 \%-1.76 \mathrm{~km}^{2}\right)$. Although apparently being a considerable amount of vegetation, multiple street segments of the study area are lacking forestry coverage (Figure 2A). Gardens represent the largest proportion of herbaceous vegetation $\left(31.10 \%-2.27 \mathrm{~km}^{2}\right)$, followed by parks $\left(22.15 \%-1.61 \mathrm{~km}^{2}\right)$ (Table 1$)$. Considering gardens, the most relevant different types were distributed in small and medium/height residential buildings, leisure facilities, religious and education institutions, small and medium/height commercial buildings and warehouses (Figure 2B). However, despite the large amount of vegetation within this urban landscape and the wide variety of elements, these are concentrated at the southern portion of the study area, dominated by parks and gardens (Figure 1, Table 1).

Tabela 1. Proporções dos tipos de vegetação arbórea e herbácea encontradas na regional centro-sul do município de Belo Horizonte (Minas Gerais, Brasil)

Table 1. Proportions of woody and herbaceous vegetation found in the southern region of Belo Horizonte (Minas Gerais, Brazil)

\begin{tabular}{cc|c|c|c|c|c|c|c}
\cline { 3 - 8 } & & Parks & $\begin{array}{c}\text { Streets/ } \\
\text { Squares }\end{array}$ & Gardens & Wastelands & Slums & $\begin{array}{c}\text { Mined } \\
\text { areas }\end{array}$ & Total \\
\hline Woody & $\mathbf{K m}^{2}$ & 2.75 & 1.76 & 1.31 & 0.68 & 0.35 & 0.30 & 7.15 \\
Vegetation & $\%$ & 38.51 & 24.63 & 18.38 & 9.57 & 4.77 & 4.14 & 100 \\
$\begin{array}{ccc}\text { Herbaceous } \\
\text { Vegetation }\end{array}$ & $\mathbf{K m}^{2}$ & 1.61 & 1.45 & 2.27 & 1.10 & 0.23 & 0.63 & 7.29 \\
& 22.15 & 19.88 & 31.10 & 15.11 & 3.09 & 8.67 & 100 \\
\hline
\end{tabular}



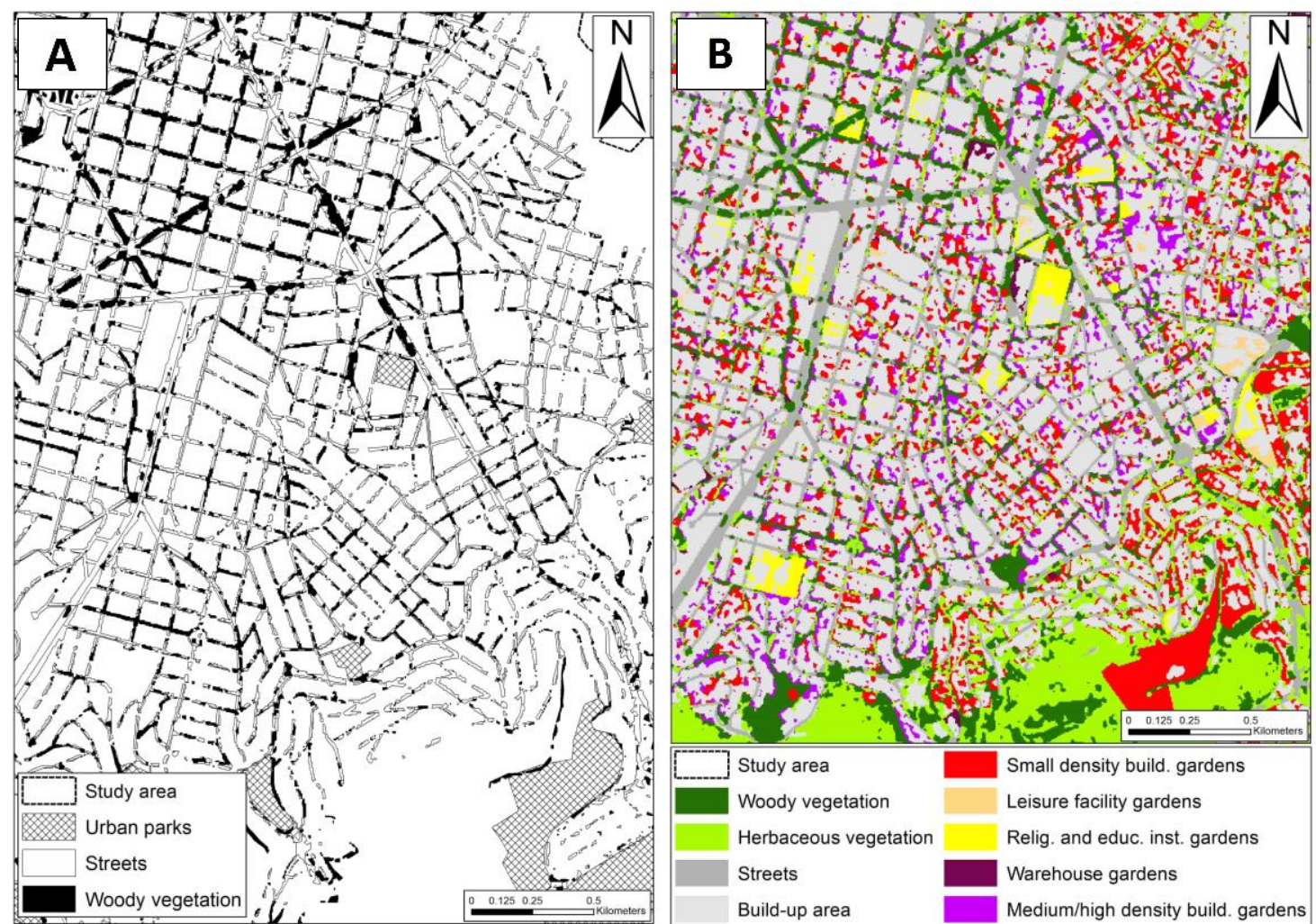

Figura 2. A - Vegetação arbórea (em preto) distribuída pelas ruas (linhas) da regional centro-sul do município de Belo Horizonte (Minas Gerais, Brasil). Os parques municipais estão destacados em quadriculado. B - Diferentes tipos de jardins identificados pela regional centro-sul de Belo Horizonte. As vegetações arbórea e herbácea encontradas em parques e outros espaços públicos (como praças e ruas) estão representados em verde escuro e claro

Figure 2. A - Woody vegetation (black) distributed through the streets (lines) of the southern region of Belo Horizonte (Minas Gerais, Brazil). The municipal parks are highlighted in checkers. B Different types of gardens identified through the southern region of Belo Horizonte. The woody and herbaceous vegetation within parks and other public spaces (e.g.: squares and streets) are represented in dark and light green, respectively

Urban parks are sources of resources for different organisms and are responsible to maintain viable species populations inside and in the vicinity of urban landscapes. Management strategies can be adopted around these protected areas, helping their preservation and in fulfilling their ecosystem functions. A surrounding matrix composed of less urbanized regions and more gardens and green spaces have less negative effects on urban parks (IKIN et al., 2013). Thus, the current characteristics of the landscape surrounding most of the urban parks located at the southern region of the study area should be maintained, such as the concentration of houses and gardens. In fact, gardens can be spatially arranged to maximize total habitat area and minimize isolation between habitat patches (GODDARD; DOUGILL; BENTON, 2010). In this way, these green elements can be used to increase the urban connectivity, especially between the isolated municipal parks located in the inner city.

Within our study area, gardens harbour a considerable amount of herbaceous and woody vegetation. This is observed in other urban landscapes, despite the current world 
tendency towards reduction of the proportion of area dedicated to gardens (CAMERON et al., 2012). These green elements are mostly influenced by the decisions of their householders (CAMERON et al., 2012; SMITH et al., 2006), being the vegetation located within gardens highly heterogeneous, promoting great potential for urban biodiversity conservation (SMITH et al., 2006). Within our study area it is possible to find different types of gardens, located in city blocks under different land use types (e.g.: schools, private and public gardens and commercial zones), and consequently under different management types and intensities.

To increase gardens' value to biodiversity native plant species must be used during its landscaping. In the Brazilian city of São Luís (Maranhão state), endangered Brazilian tree species, such as Caesalpinia echinata Lam. "pau-brasil", are protected within gardens due to the extensive use of native species (AKINNIFESI et al., 2010). In Palmas (Brazilian state of Tocantins), the use of native tree species helps in native bird species conservation within the urban landscape (REIS; LÓPEZ-IBORRA; PINHEIRO, 2012). Gardens will never replace natural and semi-natural environments, but can be a useful complement to these habitats (CAMERON et al., 2012), serving as a repository for indigenous species of animals and plants, including those threatened by extinction in nature (AKINNIFESI et al., 2010). Considering that each garden has its peculiarities due to the different decisions of their householders, they should be encouraged to adopt strategies that favour the maintenance and preservation of local biodiversity. In this way, the different types of gardens located within the southern region of Belo Horizonte will be able not only to increase the landscape permeability, but also to act as important sources of resources inside of the urban landscape (SMITH et al., 2006). Formally protected areas are not the only green infrastructure elements with potential for biodiversity conservation, especially in urban landscapes (COLDING; LUNDBERG; FOLKE, 2006).

Through the southern region of Belo Horizonte, each of the 10 most dominant tree species was represented by over 2000 individuals; together, these species accounted for $41 \%$ of all 90,000 street trees (Table 2). Four are Brazilian native species and six are exotic species. The three most abundant species are Caesalpinia peltophoroides Benth. "falso-pau-brasil" with 6431 individuals, Syagrus romanzoffiana (Cham.) Glassman "palmeira-real" 5638 individuals both native species in Belo Horizonte - and the exotic Tabebuia rosea (Bertol.) DC. "ipê-rosa" 3850 individuals, highly used in the urban forestry throughout Belo Horizonte (J.C.C. Pena pers. obs.). In general, most species are represented by less than 1000 individuals (Figure 3). 
Tabela 2. As 10 espécies mais abundantes de árvores plantadas nos logradouros públicos de Belo Horizonte (Minas Gerais, Brasil), suas abundâncias e suas distribuições originais

Table 2. The 10 most abundant street tree species distributed through the southern region of Belo Horizonte (Minas Gerais, Brazil), their abundances and original distributions

\begin{tabular}{|c|c|c|c|}
\hline Species & Common name & $\begin{array}{l}\text { Abundance } \\
(\%)\end{array}$ & Native to \\
\hline Caesalpinia peltophoroides Benth. & "Falso-pau-brasil" & $6431(7.22)$ & Brazil \\
\hline Syagrus romanzoffiana (Cham.) Glassman & "Palmeira-real" & $5638(6.33)$ & Brazil \\
\hline Tabebuia rosea (Bertol.) DC. & "Ipê-rosa" & $3850(4.32)$ & $\begin{array}{l}\text { North and Central } \\
\text { America }\end{array}$ \\
\hline Dypsis lutescens (H. Wendl.) Beentje \& J. Dransf. & "Areca-bambu" & $3810(4.27)$ & Madagascar \\
\hline Ligustrum lucidum W.T. Aiton & "alfeneiro" & $3623(4.06)$ & Asia \\
\hline Tibouchina granulosa (Desr.) Cogn. & "Quaresmeira" & $3470(3.90)$ & Brazil \\
\hline Michelia champaca L. & $\begin{array}{l}\text { "Magnólia- } \\
\text { amarela" }\end{array}$ & $2563(2.88)$ & Asia \\
\hline Murraya exotica L. & "Murta-de-cheiro" & $2552(2.86)$ & Asia \\
\hline Cupressus sp. & "Cipreste-italiano" & $2344(2.63)$ & Northern Hemisphere \\
\hline Pachira aquatica Aubl. & "Monguba" & $2255(2.53)$ & $\begin{array}{l}\text { Central and South } \\
\text { America (Brazil) }\end{array}$ \\
\hline
\end{tabular}

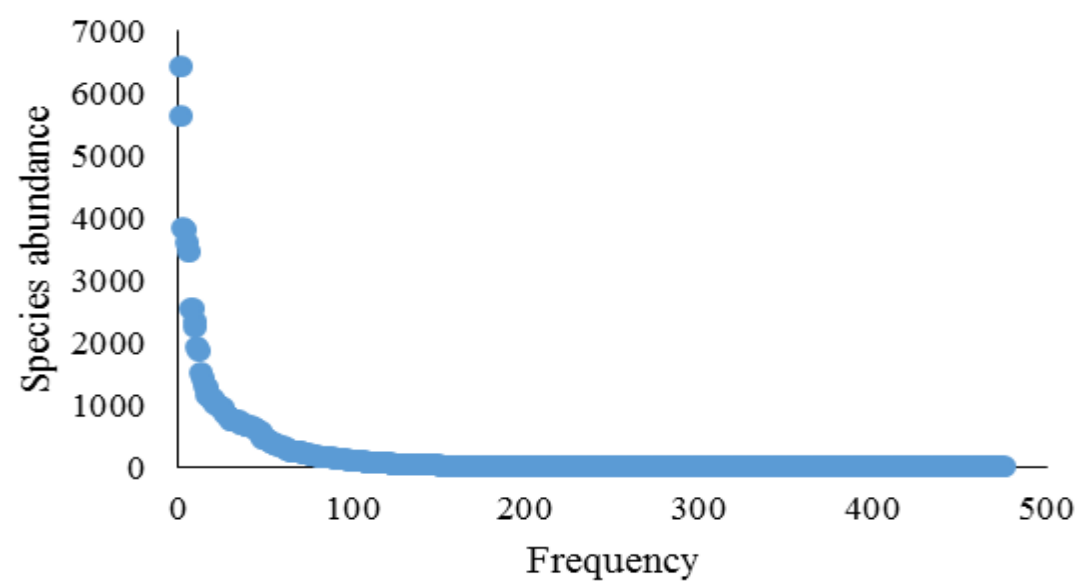

Figura 3. Frequências das abundâncias das espécies de árvores plantadas nos logradouros públicos da regional centro-sul do município de Belo Horizonte (Minas Gerais, Brasil). É possível observar que a maior parte das espécies é representada por menos que 1000 indivíduos

Figure 3. Frequency of the abundances of the street tree species through the southern region of Belo Horizonte (Minas Gerais, Brazil). It is possible to observe that most species are represented for less than 1000 individuals

The urban forestry process plays an important role within urban landscapes. Street trees' species composition have influence on bird feeding guilds that use a street's vegetation (YOUNG; DANIELS; JOHNSTON, 2007). The number of trees in the streets (FONTANA; BURGER; MAGNUSSON, 2011) and the amount of native species (IKIN et al., 2013) leads to an increase in bird species richness, as there is a greater variety and availability of resources. The current composition of the street tree's community in the study area is a consequence of 
the preference for a few tree species, manly exotic and with striking flowers. This aesthetic view of the urban forestry process does not consider the landscape functionality. As a consequence, we observe this great dominance of species such as $T$. rosea, $C$. peltophoroides and Tibouchina granulosa (Desr.) Cogn. "quaresmeira" - tree symbol of Belo Horizonte. Furthermore, the great abundance of Dypsis lutescens ( $\mathrm{H}$. Wendl.) Beentje \& J. Dransf. "arecabambu" and Murraya exotica L. "murta-de-cheiro" are indicative of a replacement process of trees for shrubby species. Since shrubby and small tree species usually produce less organic material such as fruits and leaves, there is a preference of these species by the human population. The deficient street forestry, the reduced species diversity, the great use of exotic species and the growing use of shrubby species reduces the role of urban forestry, not only in preserving biodiversity, but also in maintaining important ecosystem services, such as the reduction of storm water runoff (SOARES et al., 2011). Therefore, an investment in planting of street trees is needed, and the selected species must have the necessary characteristics to increase the functionality of the urban forest. Streets and other urban linear elements can be used to increase the connectivity of the urban landscape. Differentiated management can be used in streets and roads that connect parks and cross less urbanized areas, serving as green urban corridors or linear urban parks, for human - as cyclist and walking tracks - and nonhuman organisms (MAGALHÃES; MOURA, 2013), such as the streets and avenues that connect the urban parks located within central region of the study area.

When properly managed, wastelands, roadside grass and empty spaces between road junctions can provide important ecosystem services within urban landscapes. They can act not only as stepping stones for the movement of animal species, but sources of resources within the urban landscape (SITZIA; CAMPAGNARO; WEIR, 2015). In Berlin (Germany), the vegetation structure in wastelands influences the presence of urban birds with 12 species of European conservation concern within these green elements (MEFFERT; DZIOCK, 2012). In Belo Horizonte, wastelands and roadside grass can be used as pocket parks to help in the conservation of urban biodiversity and to increase the landscape permeability along with other green elements, such as gardens and parks.

The slums, neglected areas in large cities in developing countries, are a strong example of poor urban planning. Millions of people live in these regions, without basic services and in unhealthy living conditions. This is mostly related due to the spontaneous and irregular occupation of the land due to human migration to urban centres. Thus, the green infrastructure planning rarely is considered in attempts to improve the population's quality of life. Within the slums of our study area (which represent $7.47 \%$ of the build-up area), there is a small amount of vegetation, but it was not possible to identify its use due the lack of urban planning. The few forest patches located near and inside the slums are extremely important for slope protection 
(the regions in which the slums are located in the study area have a pronounced declivity). However, the population does not have direct access to these areas. Thus, we highlight the importance of the green infrastructure in rehabilitation and urbanization projects of slums. In Belo Horizonte's slums, the creation of community gardens and allotments with community participation will enhance their connection with nature, and increase their interest related to conservation issues, their health and well-being. In Stockholm, allotments provide cultivated vegetables and fruits for self-sufficiency and recreation (COLDING; LUNDBERG; FOLKE, 2006).

The remaining amount of vegetation within the study area is located within abandoned mines, which also border the largest protected areas. One of the conditions for permitting dolomite extraction was to transform the area into a park after the mine's closure. Today, four years after the end of extraction, no rehabilitation activity has been performed in the area, leaving a portion of the symbol of the city of Belo Horizonte, the Serra do Curral National Heritage Site, completely degraded. Considering the proximity of the Belo Horizonte's mined areas with its inhabitants and with important native habitat patches, it is of utmost importance that these regions are rehabilitated and used for social and environmental purposes. Abandoned mines can be reclaimed for social, economic and even environmental functions.

\section{CONCLUSIONS}

This study is the first step towards a better understanding of how Belo Horizonte's landscape influences local biodiversity and can be used to guide the use of urban green infrastructure to increase its resilience and functionality. Next steps include the use of landscape metrics and information on biodiversity that inhabits the city to understand the functionality of this urban ecosystem. Although being used since the 1960's, the Map Algebra methodology can be a useful tool for the combination of factors in order to assist in urban planning, especially with digital technology support that favors adjustments and calibrations. Using this procedure, our results show that private properties and street trees harbour a considerable amount of vegetation within this urban landscape, reinforcing the importance of showing to the urban population that biodiversity conservation is not restricted to formally protected areas; therefore, requiring an integrated planning of the green infrastructure. Each of the elements of the green infrastructure has distinct historical uses and different levels of impact, presenting relevant functions within urban landscapes. But to achieve their full potential, it is important a holistic view that considers besides the organisms (human and nonhuman) directly affected by them, the social, environmental and economic roles in which they can be involved. 


\section{ACKNOWLEDGEMENTS}

We thank CNPq, CAPES and FAPEMIG for financial support and Belo Horizonte's Municipality for providing the SIIA-BH data.

\section{REFERENCES}

AKINNIFESI, F. K.; SILESHI, G. W.; AJAYI, O. C.; AKINNIFESI, A. I.; DE MOURA, E. G.; LINHARES, J. F. P.; RODRIGUES, I. Biodiversity of the urban homegardens of São Luís city, northeastern Brazil. Urban Ecosystems, Nova lorque, v. 13, n. 1, p. 129 - 146, 2010.

BELO HORIZONTE. Lei No 7.166, de 27 de Agosto de 1996. Disponível em: <http://cm-belohorizonte.jusbrasil.com.br/legislacao/237741/lei-7166-96>

BELO HORIZONTE. Prefeitura Municipal de Belo Horizonte. Disponível em: <http://portalpbh.pbh.gov.br/pbh/> Acesso em: 09 out. 2016.

CAMERON, R. W. F.; BLANUŠA, T.; TAYLOR, J. E.; SALISBURY, A.; HALSTEAD, A. J.; HENRICOT, B.; THOMPSON, K. The domestic garden - Its contribution to urban green infrastructure. Urban Forestry \& Urban Greening, Davis, v. 11, n. 2, p. 129 - 137, 2012.

COLDING, J.; LUNDBERG, J.; FOLKE, C. Incorporating green-area user groups in urban ecosystem management. Ambio, Estocolmo, v. 35, n. 5, p. 237 - 244, 2006.

DUARTE, R. H. À sombra dos fícus: cidade e natureza em Belo Horizonte. Ambiente \& Sociedade, São Paulo, v. 10, n. 2, p. 25 - 44, 2007.

FONTANA, C. S.; BURGER, M. I.; MAGNUSSON, W. E. Bird diversity in a subtropical SouthAmerican City: effects of noise levels, arborisation and human population density. Urban Ecosystems, Nova lorque, v. 14, n. 3, p. 341 - 360, 2011.

GODDARD, M. A.; DOUGILL, A. J.; BENTON, T. G. Scaling up from gardens: biodiversity conservation in urban environments. Trends in Ecology \& Evolution, Amsterdam, v. 25, n. 2, p. $90-98,2010$.

GUÉNARD, B.; CARDINAL-DE CASAS, A.; DUNN, R. R. High diversity in an urban habitat: are some animal assemblages resilient to long-term anthropogenic change? Urban Ecosystems, Nova lorque, v. 18, n. 2, p. 449 - 463, 2014.

HERZOG, C. P. Cidade para todos: (re) aprendendo a viver com a natureza. Rio de Janeiro: Mauad, Inverde, 2013. 213p.

IKIN, K.; KNIGHT, E.; LINDENMAYER, D. B.; FISCHER, J.; MANNING, A. D. The influence of native versus exotic streetscape vegetation on the spatial distribution of birds in suburbs and reserves. Diversity and Distributions, Hoboken, v. 19, n. 3, p. $294-306,2013$.

KENIGER, L. E.; GASTON, K. J.; IRVINE, K. N.; FULLER, R. A. What are the benefits of interacting with nature? International Journal of Environmental Research and Public Health, Basel, v. 10, n. 3, p. 913 - 35, 2013. 
MAGALHÃES, D. M.; MOURA, A. C. M. Landscape morphology metrics for urban areas: analysis of the role of vegetation in the management of the quality of urban environment. DISEGNARECON - Atti Dei Seminari, Bolonha, v. 6, n. 11, p. 81 - 92, 2013.

MCDONALD, R. I.; MARCOTULLIO, P. J.; GÜNERALP, B. Urbanization and Global Trends in Biodiversity and Ecosystem Services. In ELMQVIST T.; FRAGKIAS, M.; GOODNESS, J.; GÜNERALP, B.; MARCOTULLIO, P. J.; MCDONALD, R. I.; PARNEL, S.; SCHEWENIUS, M.; SENDSTAD, M.; SETO, K. C.; WILKINSON, C. (Orgs.), Urbanization, Biodiversity and Ecosystem Services: Challenges and Opportunities. Dordrecht: Springer Netherlands, 2013. p. $31-52$.

MCHARG, I. Design with nature. Garden City: Natural History Press,1969. 197p.

MEFFERT, P. J.; DZIOCK, F. What determines occurrence of threatened bird species on urban wastelands? Biological Conservation, Amsterdam, v. 153, p. 87 - 96, 2012.

MORO, M. F.; CASTRO, A. S. F. A check list of plant species in the urban forestry of Fortaleza, Brazil: where are the native species in the country of megadiversity? Urban Ecosystems, Nova lorque, v. 18, n. 1, p. 47 - 71, 2015.

ORTEGA-ÁLVAREZ, R.; MACGREGOR-FORS, I. Living in the big city: Effects of urban landuse on bird community structure, diversity, and composition. Landscape and Urban Planning, Amsterdam, v. 90, n. 3-4, p. 189 - 195, 2009.

PAUCHARD, A.; BARBOSA, O. (2013). Regional Assessment of Latin America: Rapid Urban Development and Social Economic Inequity Threaten Biodiversity Hotspots. In Urbanization, Biodiversity and Ecosystem Services: Challenges and Opportunities. Dordrecht: Springer Netherlands, 2013. p. 589 - 608.

REIS, E.; LÓPEZ-IBORRA, G. M.; PINHEIRO, R. T. Changes in bird species richness through different levels of urbanization: Implications for biodiversity conservation and garden design in Central Brazil. Landscape and Urban Planning, Amsterdam, v. 107, n. 1, p. 31 - 42, 2012.

SITZIA, T.; CAMPAGNARO, T.; WEIR, R. G. Novel woodland patches in a small historical Mediterranean city: Padova, Northern Italy. Urban Ecosystems, Nova lorque, v. 19, n. 1, p. $475-487,2015$.

SMITH, R. M.; THOMPSON, K.; HODGSON, J. G.; WARREN, P. H.; GASTON, K. J. Urban domestic gardens (IX): Composition and richness of the vascular plant flora, and implications for native biodiversity. Biological Conservation, Amsterdam, v. 129, n. 3, p. 312 - 322, 2006.

SOARES, A. L.; REGO, F. C.; MCPHERSON, E. G.; SIMPSON, J. R.; PEPER, P. J.; XIAO, Q. Benefits and costs of street trees in Lisbon, Portugal. Urban Forestry \& Urban Greening, Amsterdam, v. 10, n. 2, p. 69 - 78, 2011

UNITED NATIONS. World Urbanization Prospects: the 2014 Revision. New York: UnitedNations, Department of Economic and Social Affairs, Population Division, 2014. 517p

YOUNG, K. M.; DANIELS, C. B.; JOHNSTON, G. Species of street tree is important for southern hemisphere bird trophic guilds. Austral Ecology, Nova lorque, v. 32, n. 5, p. 541 550, 2007. 